\title{
Nordiques
}

36 | 2018

Réformer l'éducation en Europe du Nord

\section{Éric Eydoux, Le chemin de la trahison. La Norvège à l'heure de Quisling}

Gaïa, 2018

Hervé Sévère

\section{(2) OpenEdition}

Journals

Édition électronique

URL : http://journals.openedition.org/nordiques/538

DOI : $10.4000 /$ nordiques. 538

ISSN : 2777-8479

Éditeur :

Association Norden, Bibliothèque de Caen la mer

Édition imprimée

Date de publication : 1 novembre 2018

Pagination : 130-131

ISBN : 9791095914020

ISSN : $1761-7677$

\section{Référence électronique}

Hervé Sévère, «Éric Eydoux, Le chemin de la trahison. La Norvège à l'heure de Quisling », Nordiques [En ligne], 36 | 2018, mis en ligne le 31 octobre 2020, consulté le 14 mars 2021. URL : http:// journals.openedition.org/nordiques/538; DOI : https://doi.org/10.4000/nordiques.538

Ce document a été généré automatiquement le 14 mars 2021.

Nordiques 


\title{
Éric Eydoux, Le chemin de la trahison. La Norvège à l'heure de Quisling
}

Gaïa, 2018

\author{
Hervé Sévère
}

\section{RÉFÉRENCE}

Éric Eydoux, Le chemin de la trahison. La Norvège à l'heure de Quisling, Gaïa, 2018

1 Le 9 avril 1940 au petit matin, les troupes allemandes se lancèrent à l'assaut de la Norvège. Pays neutre depuis toujours, n'entretenant qu'un embryon d'armée, la Norvège n'était nullement préparée à cette agression. En quelques heures, la Wehrmacht occupa villes principales et sites stratégiques du pays. Seul le torpillage d'un croiseur lourd dans le fjord d'Oslo permit au roi et à l'exécutif de quitter la capitale en catastrophe, puis de gagner Londres, où ils formèrent un gouvernement en exil.

2 À l'origine, l'invasion de la Norvège n'entrait pas dans les plans d'Hitler. L'idée lui en avait été tardivement soufflée par Vidkun Quisling, le chef du petit parti nazi norvégien. Ne réussissant pas à s'imposer dans les urnes, il avait proposé au Führer de lui ouvrir les portes du royaume en échange de son aide pour instaurer un régime autoritaire allié de l'Allemagne. Pour justifier ce coup de force, Quisling avait principalement fait valoir qu'il fallait empêcher les alliés de couper la "route du fer » qui passait par la Norvège.

3 En vérité, immédiatement discrédité par cette trahison, le « Förer » ne parvint jamais à s'imposer. Et c'est seulement parce qu'Hitler lui imposa la présence de Josef Terboven, un « Reichskommissar » d'une rare brutalité, que son régime put tenir. Car, très tôt, la population norvégienne fit majoritairement front pour contrer les exigences du nouveau pouvoir. Organisations professionnelles, associations sportives, enseignants, 
Église... tous s'engagèrent à leur niveau contre l'ennemi, parfois au prix de leur vie. Ce fut le holdningskamp, «le front du refus », forme de résistance passive, prémisses d'une résistance active qui apparaîtra plus tardivement, en 1944.

4 Éric Eydoux, spécialiste des pays nordiques, est l'auteur d'ouvrages de référence consacrés à l'histoire et à la littérature norvégiennes. Dépassant la simple présentation factuelle chronologique, l'auteur suit le parcours d'un homme d'une rare intelligence, mais psychologiquement instable (la recherche d'après-guerre le jugea atteint de mégalomanie paranoïaque), qui se rêvait en sauveur de la Norvège et restaurateur de sa grandeur passée quand les Norvégiens n'avaient pour lui que mépris. Analysant remarquablement les faits et gestes de Quisling, ses décisions, mais aussi et surtout son état d'esprit, ses doutes et ses contradictions, Éric Eydoux présente un portrait rigoureux et documenté du traître Quisling que ses convictions jamais reniées condamneront à la peine capitale, pourtant abolie en 1902, mais réintroduite dans le droit norvégien en 1941 par le gouvernement en exil soucieux de préparer l'aprèsguerre. La peinture de Quisling faite par Éric Eydoux apporte un éclairage nouveau au lecteur français.

5 Premier livre en français consacré à l'occupation de la Norvège, il vient pallier l'absence de documentation. Il offre de plus une synthèse de nombreux travaux tant nordiques qu'étrangers, dont on trouvera les références dans la bibliographie finale, qui propose à la fois des ouvrages documentaires et des œuvres de fiction. Alliant la rigueur scientifique à l'élégance de l'écriture, Le chemin de la trahison est d'une lecture extrêmement plaisante. Sa riche iconographie est issue des archives nationales norvégiennes et du musée de la Résistance à Oslo.

Il est appelé à devenir un document de référence dans la bibliographie francophone sur l'histoire de la Norvège. 